Sasa T. Zivanovic

Associate-Professor University of Belgrade Faculty of Mechanical Engineering Department of Production Engineering

Mihajlo D. Popovic

Assistant-Professor University of Belgrade Faculty of Mechanical Engineering Department of Production Engineering

Nikola M. Vorkapic

Teaching Assistan University of Belgrade Faculty of Mechanical Engineering Department of Production Engineering

Milos D. Pjevic

Teaching Assistan University of Belgrade Faculty of Mechanical Engineering Department of Production Engineering

Nikola R. Slavkovic

Assistant-Professor University of Belgrade Faculty of Mechanical Engineering Department of Production Engineering

\section{An Overview of Rapid Prototyping Technologies using Subtractive, Additive and Formative Processes}

This paper describes methodology for application of a rapid prototyping using subtractive, additive and formative technology based on STL files. Rapid prototyping technology includes using of a digital information chain $C A D / C A M / C N C$ to a level which allows the successful realization of the physical models based on new technologies by adding, subtracting and molding material. The paper discusses about the usual technologies for rapid prototyping, for which a generalized methodology for their application has been proposed. The possibilities for program verification prior to the realization of the model were also shown. The methodology is verified on real examples of making selected parts. Used technologies are subtracting and adding material layers, layer by layer, and mold making (by adding material) for molding the silicone model.

Keywords: rapid prototyping, STL, additive technology, subtractive technology, 3D printing, desktop milling, verification, simulation

\section{INTRODUCTION}

Rapid prototyping (RP) has emerged as a key enabling technology with its ability to short product design and development time. Rapid prototyping is a technology for quickly fabricating physical models, functional prototypes and small series of parts directly from CAD models $[1,2]$. The rapid prototyping is used in a variety of industries to describe a process for rapidly creating a part representation before final realization or commercialization [3]. The main advantage of the rapid prototyping technologies is that almost any shape can be produced. Time and money savings vary from $50-90 \%$ compared to conventional systems [4].

This technology has also been referred to as layer manufacturing, solid free-form fabrication, material addition manufacturing, 3D printing, computer automated manufacturing or layered manufacturing $[1,2,4]$. Development of computers and software for the CAD product design, that also include 3D modeling of different prototypes, and with rapidly progress of technologies to produce realistic physical models enable to overcome the shortcomings of traditional methods of prototyping. These RP technologies are used for creating a very complex models $[5,6]$.

Nowadays, there are already many manufacturers of machines and equipments for rapid prototyping, and also there are a lot of different technologies for rapid prototyping. Classification of RP technologies could be made upon different criteria [7-9]. One of basic classifi-

Received: September 2019, Accepted: November 2019 Correspondence to: Prof. Sasa Zivanovic, University of Belgrade, Faculty of Mechanical Engineering, Kraljice Marije 16, 11120 Belgrade 35, Serbia E-mail: szivanovic@mas.bg.ac.rs doi:10.5937/fmet2001246Z

(C) Faculty of Mechanical Engineering, Belgrade. All rights reserved cation is according to the method of making of prototype, Figure 1.

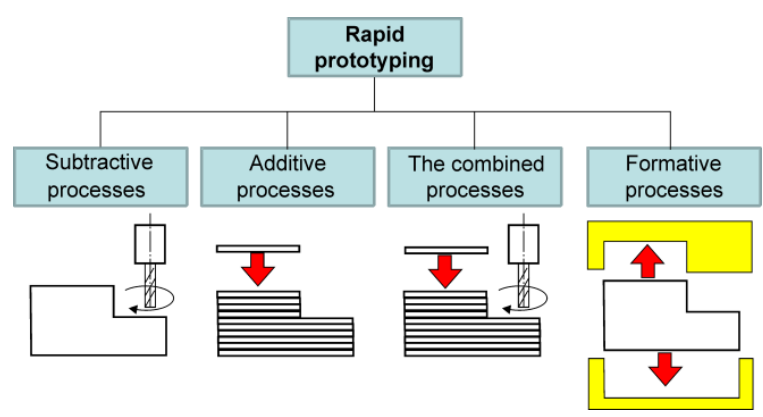

Figure 1. Basic classification of rapid prototyping

There are four fundamental fabrication processes [8] as shown in Figure 1. They are (i) subtractive, (ii) additive, (iii) combined (subtractive and additive) and (iv) formative processes.

In the subtractive process, part fabrication starts with a single block of solid material larger than the final size of the desired object and material is removed until the desired shape is reached [8]. In the additive process, part fabrication begin with one layer to which one by one layer are added until the desired shape is reached. The combined subtractive and additive processes starts with one layer to which one by one layer are added until the approximate desired shape is reached. That approximate desired shape is finalized, usually by milling process, until the desired shape is reached.

The formative process includes restricting forms in order to form the desired shape from material according to them [8], for example plastic injection molding, silicone molding, etc. Formative processes, for a small series of prototypes, involve the manufacture of molds or models in the prior processes, in order to make casting mold halves. 
The subject of this paper is the establishment of a methodology for the application of basic rapid prototyping technologies based on the model in the STL format. The methodology was verified on selected examples of prototyping by adding, subtracting materials, and the silicone casting process for which the mold was obtained by the process of adding materials.

\section{METHODOLOGY FOR APPLICATION OF ADDI- TIVE, SUBTRACTIVE AND FORMATIVE TECH- NOLOGIES}

Application of RP technologies based on models in STL format basically may be an additive technology that adding material by layers, or a subtractive technology which subtracting materials by layers.

Typical process for additive technologies is shown in Figure 2 and includes following stages: (1) CAD modeling of part, (2) STL conversion - exporting STL file from CAD model and checking for defects, (3) Slicing - STL file is divided into layers by appropriate software, (4) Generating G-code, (5) Machine setup, (6) Simulation of 3D printing, (7) Fabrication of prototype, (8) Additional auxiliary operations on 3D printed model such as curing, surface polishing, finishing, etc.

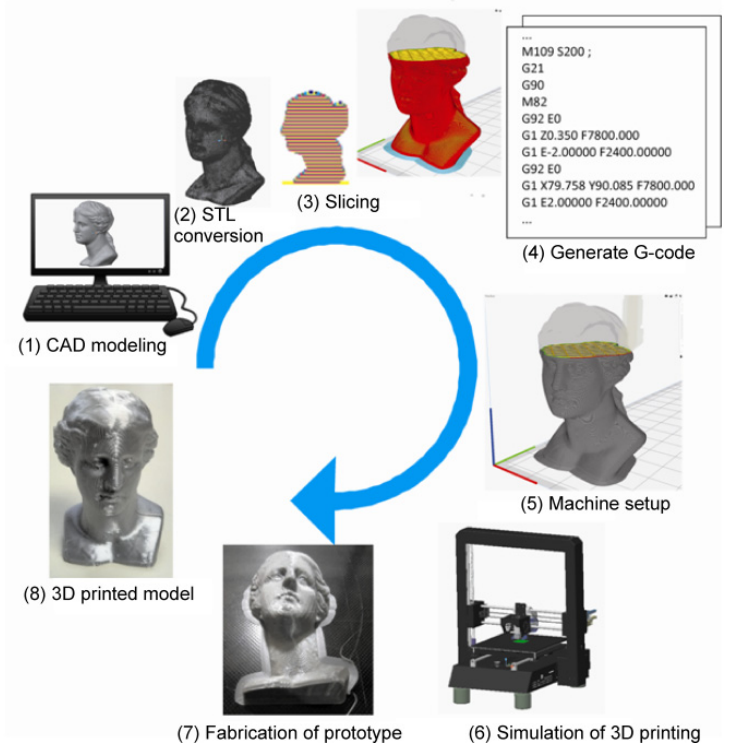

Figure 2. Rapid prototyping using additive technology based on STL files

Typical process for subtractive technology is shown in Figure 3 and includes following stages: (1) CAD modeling of part; (2) STL conversion; (3) Loading of STL file in CAM system and planning roughing and finishing strategy for milling; (4) Generating G-code; (5) Gcode verification with material removal simulation; (7) Fabrication of prototype using desktop milling.

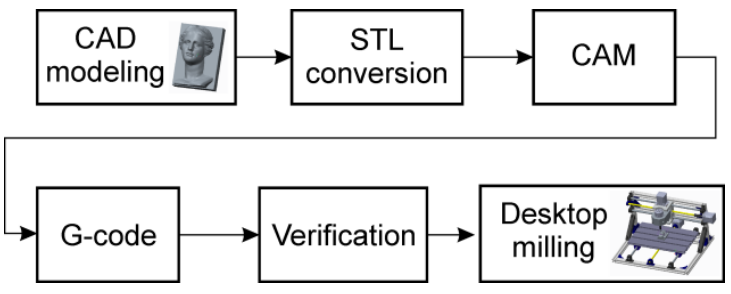

Figure 3. Rapid prototyping using subtractive technology based on STL files
Typical formative technology is shown in Figure 4 and includes the following stages: (1) CAD modeling of part; (2) STL conversion; (3) CAD generation of mold halves based on STL files in appropriate CAD environment (e.g. Fusion360 [10]); (4) 3D printing of generated mold halves; (5) Preparation of silicone and casting into molds; (6) Hardening of the silicone prototype and its finishing.
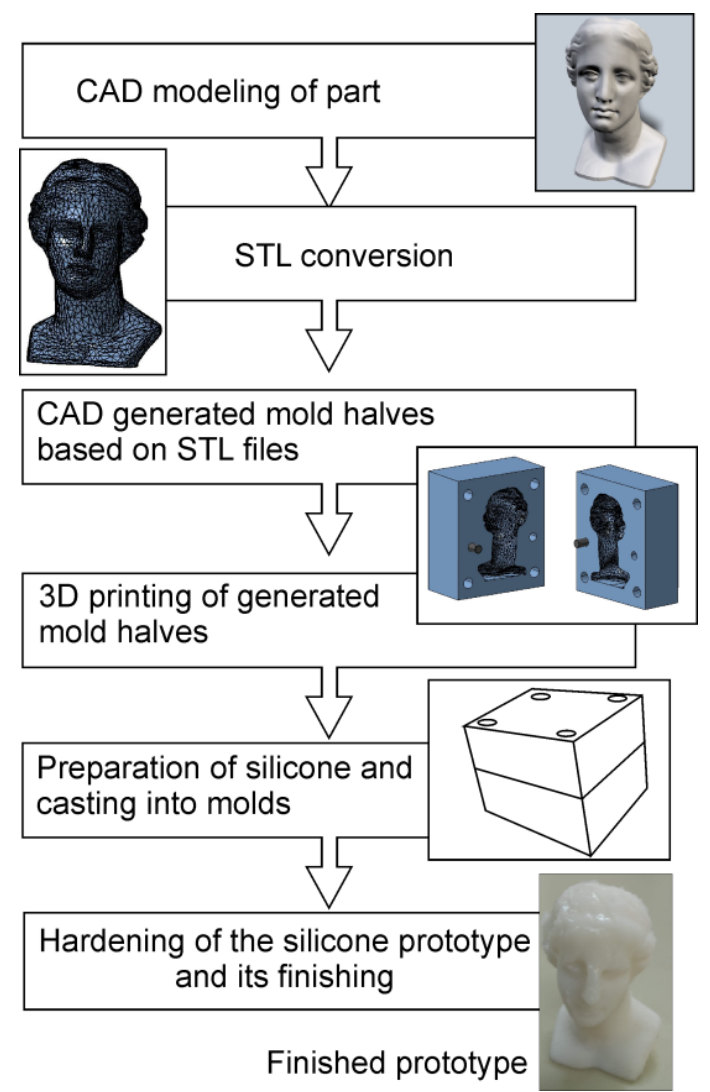

Figure 4. Rapid prototyping using formative technology based on STL files

These three basic RP technologies are integrated into the generalized methodology that describes their application, Figure 5. The IDEF0 (Integration Definition Function Modeling) diagrams [11] are used to describe methodology for RP technologies using additive, subtractive and formative technologies. The IDEF0 is used to produce a "function model". A function model is a structured representation of the functions, activities or processes within the modeled system or subject area. An IDEF0 model is composed of a hierarchical series of diagrams that gradually display increasing levels of detail describing functions and their interfaces within the context of a proposed methodology [11].

The result of applying IDEF0 to describe methodology for all considered RP technologies (additive, subtractive and formative) is a model which consists of a set of hierarchical diagrams with text descriptions. An IDEF0 diagram that provides the basic flow of activities to describe methodology for considered RP technologies is shown in Figure 5. The basic flow of activities are: A1 - Modeling or modifying of reference model CAD; A2 - Programming of additive and subtractive processes; A3 - Verification and simulation; A4 Postprocessing and A5 - Rapid prototyping (additive, subtractive, and formative processes). 


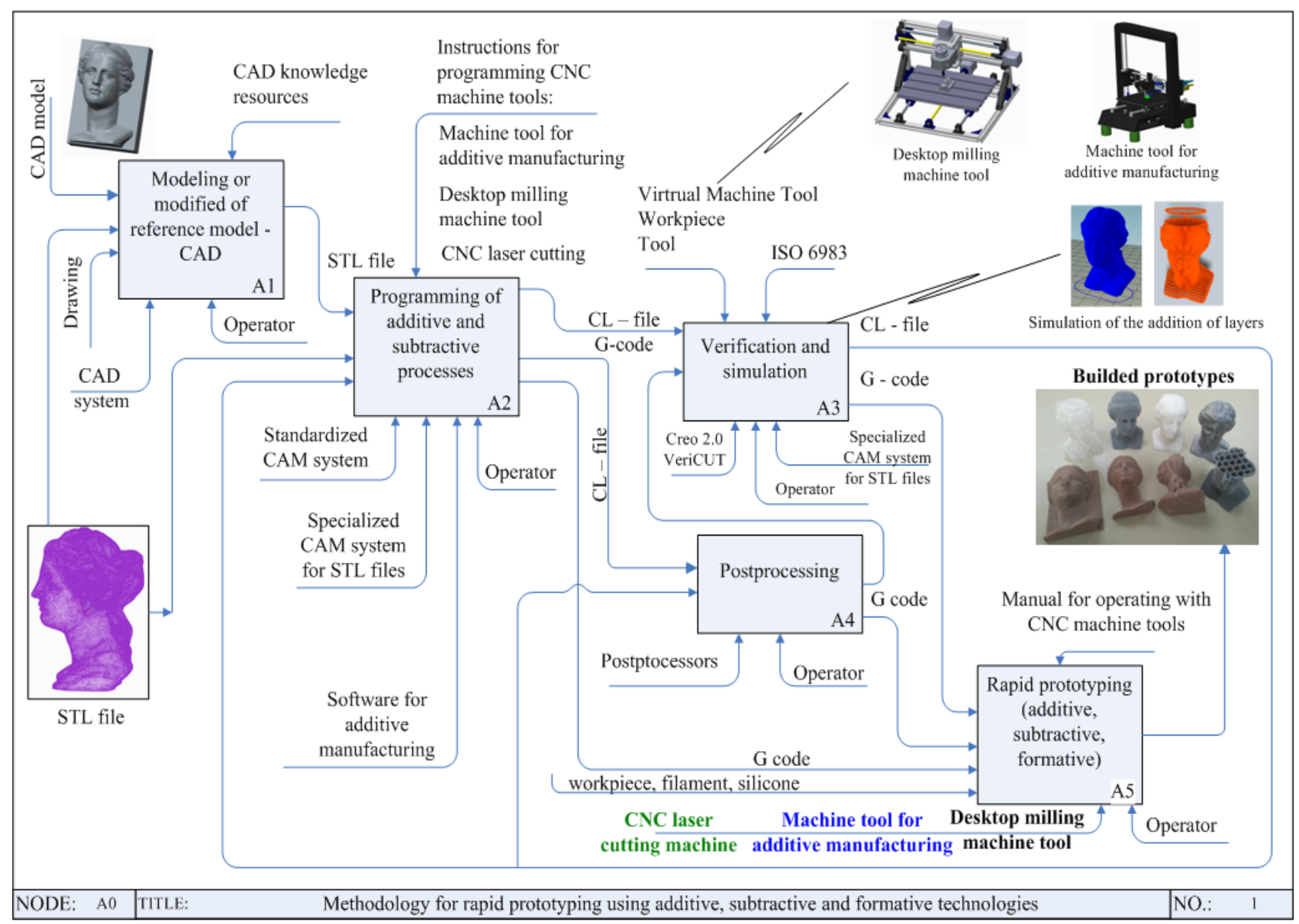

Figure 5. Methodology for rapid prototyping using additive, subtractive and formative technologies

Input to activity $\mathrm{A} 1$ can be a CAD model of part or its drawing, or a cloud of scanned points for obtaining 3D model by reverse engineering. The result of this activity is the reference model in appropriate format, i.e. STL file that is at the same time an input to the activity A2. Activity A2 represents the programming of additive or subtractive processes in order to generate toolpath for adding material, or toolpath for milling on desktop milling machines. As an output from this activity, toolpaths in the CLF or G-code format can be obtained. Standard and/or specialized CAM systems for subtraction of materials or specialized software for adding materials are available for programming. Within the scope of A3 activity, the verification of the obtained toolpaths is performed as follows: by simulation of the toolpath that include remove or addition of materials and by simulation of the obtained toolpaths on virtual machine when the machine run according to the given program. The verification of the toolpath for subtractive process is done based on the toolpath in the CLF format, in most cases, or in the $\mathrm{G}$ code format. After that, the postprocessing of the tool path (activity A4) in the G code is done and such program is transferred in the activity A5 where the prototype is fabricated on the machine. The verified toolpath for adding material is in G-code, and after the verification it can be proceed the A5 activity (without activity A4) i.e. fabrication of the prototype. The presented methodology is a digital thread $\mathrm{CAD} / \mathrm{CAM} / \mathrm{CNC}$ that allows the transition from virtual to the real world of prototype, which is made by one of the considered RP technologies.

\section{PROGRAMMING, VERIFICATION AND SIMULA- TION OF RAPID PROTOTYPING}

For the purpose of verifying the methodology presented in Section 2, the following considers the application of these methodology to the processes which involving subtractive, additive and formative technologies. In this paper, as example for illustration how to fabricate prototype based on STL file, model "Venus", Figure 6, is used.

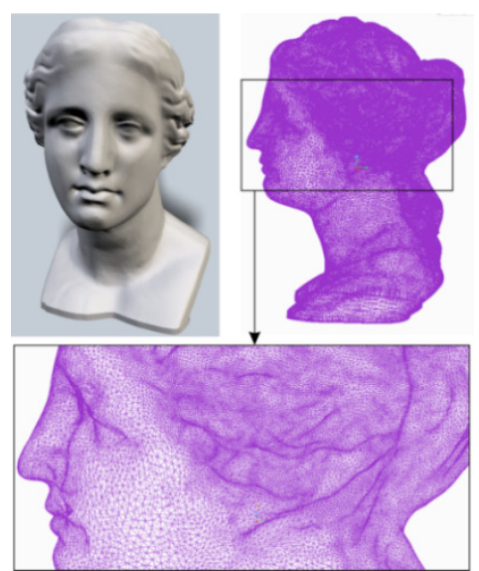

Figure 6. CAD model of the Venus and its representation in STL format

\subsection{Rapid prototyping subtractive technology}

Generating of model, i.e. STL file, and appropriate toolpath prior to fabrication of the physical models 
using subtracting technology can be done using standardized (Creo, Catia, NX Siemens,...) or specialized software for the rapid manufacturing, which allows premachining layer by layer and finally finishing.

Specialized software packages for machining based on STL file have many and some of them are CUT3D, DeskPROTO, MeshCAM, etc. These software packages enables the loading of the model in the STL format, orientating of model for machining, tool selection, choosing machining strategies for roughing and finishing, material removal simulation for different materials, and finally postprocessing the toolpath into G-code, Figure 7.

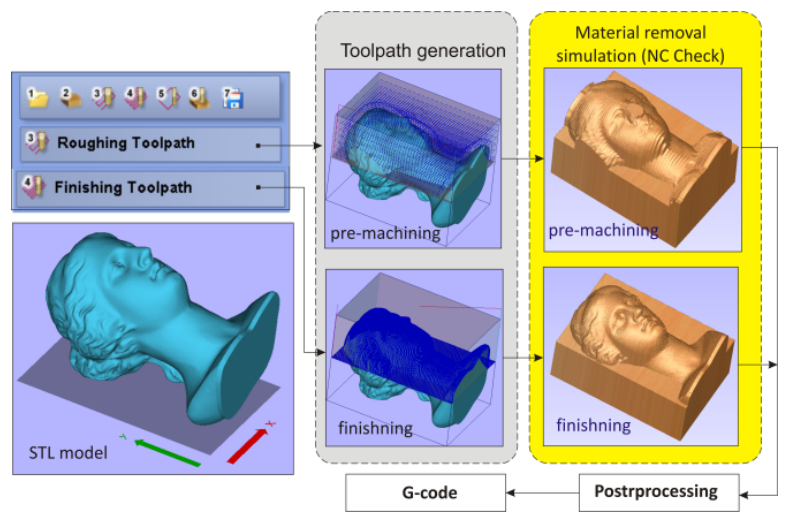

Figure 7. Rapid prototyping using subtractive technology based on STL files in CUT3D environment

\subsection{Machine simulation of subtractive manufac- turing in CAD/CAM environment}

Standardized CAD/CAM systems have possibility to configure virtual machine for the program verification. This kind of simulation is available for RP subtractive technology, in such software packages like as, for example, PTC Creo [12]. Machine simulation for the RP subtractive technology, when virtual machine run by according the program, is possible when the desktop milling machine is modeled in $\mathrm{CAD} / \mathrm{CAM}$ system with defined kinematic joints. Virtual model of the machine allows the motion of moving components as a system of rigid bodies Figure 8 .
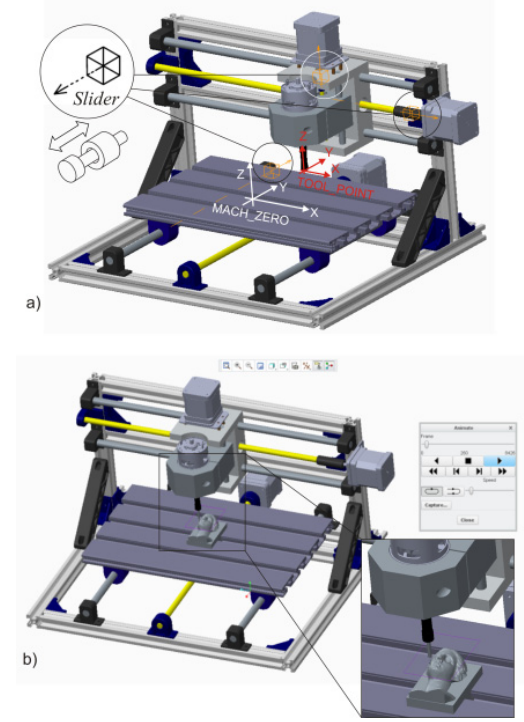

Figure 8. Machine simulation in CAD/CAM environment
Detailed virtual model of desktop milling machine (CNC3018) with all kinematic joints is shown in Figure 8a. These kinematic joints include three translatory movement along $\mathrm{X}, \mathrm{Y}$ and $\mathrm{Z}$ axes, where these axes are defined as kinematic connection type Slider. Figure 8a also shows coordinate systems MACH_ZERO on the working table, and TOOL_POINT on the tool holder for setting the tool. Matching the coordinate systems $\mathrm{MACH}$ ZZERO of workpiece and MACH_ZERO on working table enables the setting of the workpiece on the configured virtual machine. Similar is also with matching of coordinate systems TOOL_POINT on the tool and TOOL_POINT during the setting of the tool on the tool holder. After successful program verification, machining can be safely carried out on 3-axis desktop milling machine CNC3018. A example of machining of the Venus STL model is shown in Figures 9 and 10 for two different workpiece materials (Sika Block - modeling board and Rigid Foam-Styrofoam, respectively).
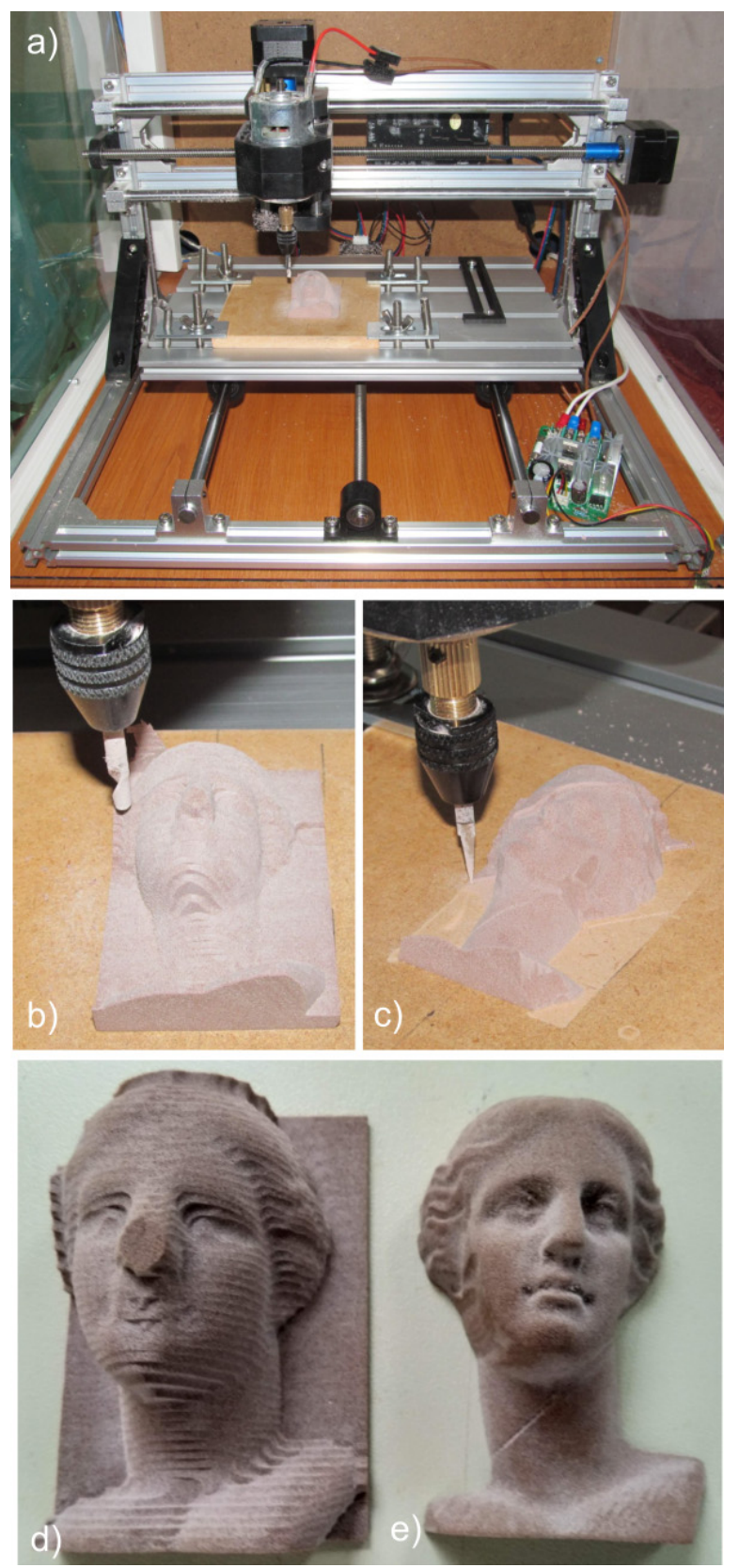

Figure 9. RP using subtractive technology during and after machining in Sika Block 

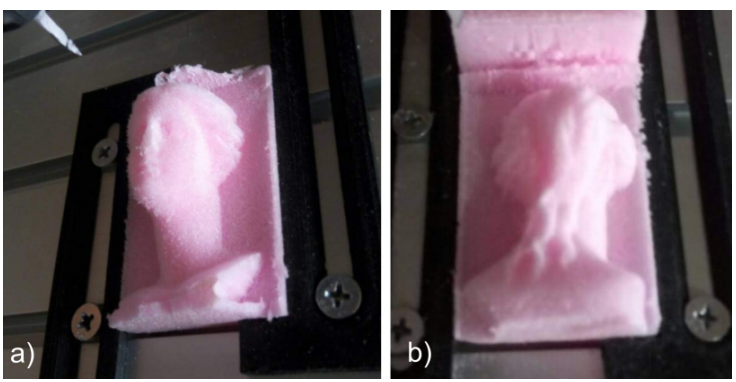

Figure 10. Rapid prototyping using subtractive technology after machining in Rigid Foam-Styrofoam

Figure 9 shows: the appearance of a complete workplace with a machine during operation (Figures 9a), premachining with flat endmill tool with diameter $3 \mathrm{~mm}$ (Fig. 9b), finishing with $\mathrm{V}$ Carve tool $0.3 \mathrm{~mm}$ (Figure 9c), appearance of machined model after pre-machining (Figure 9d) and the finished half of the model (Figures 9e). In Figure 10, a fully finished model on both sides of the Rigid Foam-Styrofoam material is shown.

\subsection{Rapid prototyping additive technology using Fused Deposition Modeling (FDM)}

For illustration of RP additive technology the same model from Figure 6 is used. In this case we used FDM technology, which is the most well-known method for doing prototypes developed by the US company Stratasys [13]. FDM approach extrudes the material through a nozzle in a controlled way. Two extrusion heads are often used so that support structures can be fabricated from a different material to facilitate part cleanup and removal. Competition has driven the price of these machines for additive technology down to such a level that individual buyers can afford their own machines at home [3].

In this paper, the Venus model was made in two ways, using the FDM technology. The first, as a complete model of the head in a vertical position and the second, where the head is divided into two halves, similar to the model obtained by milling process, for the purpose of comparison.
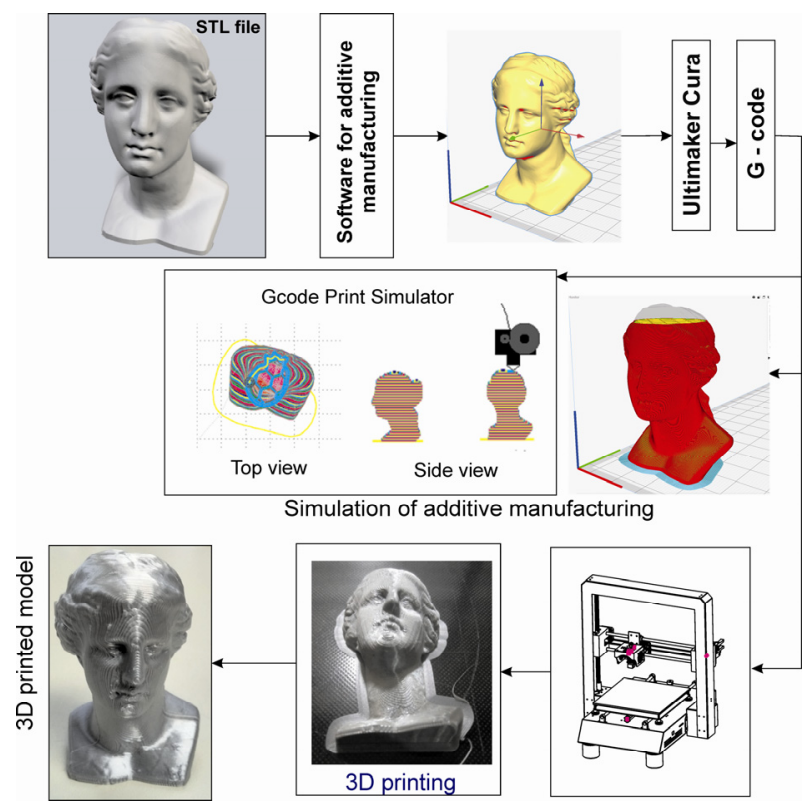

Figure 11. Rapid prototyping using FDM technology
The specialized software for additive manufacturing (Ultimaker Cura), can simulate nozzle path during the adding material, but cannot include virtual machine in simulation. On the other hand, a standard characteristic of most CAD/CAM systems is possibility of the simulation that include virtual machine tool that runs by according the program.

For now, there is a small possibility of direct simulation of the virtual machine for additive manufacturing, but this is possible to realize on indirect way in PTC Creo, by a similar way as for milling machine. This indirect method implies that the machine for additive manufacturing is modeled in the same way as the milling machine with the same kinematic joints. Machine tools for additive manufacturing can be modeled as a CAD model that includes appropriate kinematics connections. The most common machine tool for additive manufacturing are machine with only translatory axes, where these axes is defined as kinematic connections type Slider, Figure 12a.

For the workpiece the zero point is on the bottom side with the appropriate coordinate axes $\mathrm{X}, \mathrm{Y}, \mathrm{Z}$, marked as MACH_ZERO. The identical zero point (MACH_ZERO) exists on the working table of the machine on which the workpiece is placed. The tool (nozzle) coordinate system is defined in the same way as the workpiece coordinate system and marked as a TOOL_POINT, Figure 12a.

a)
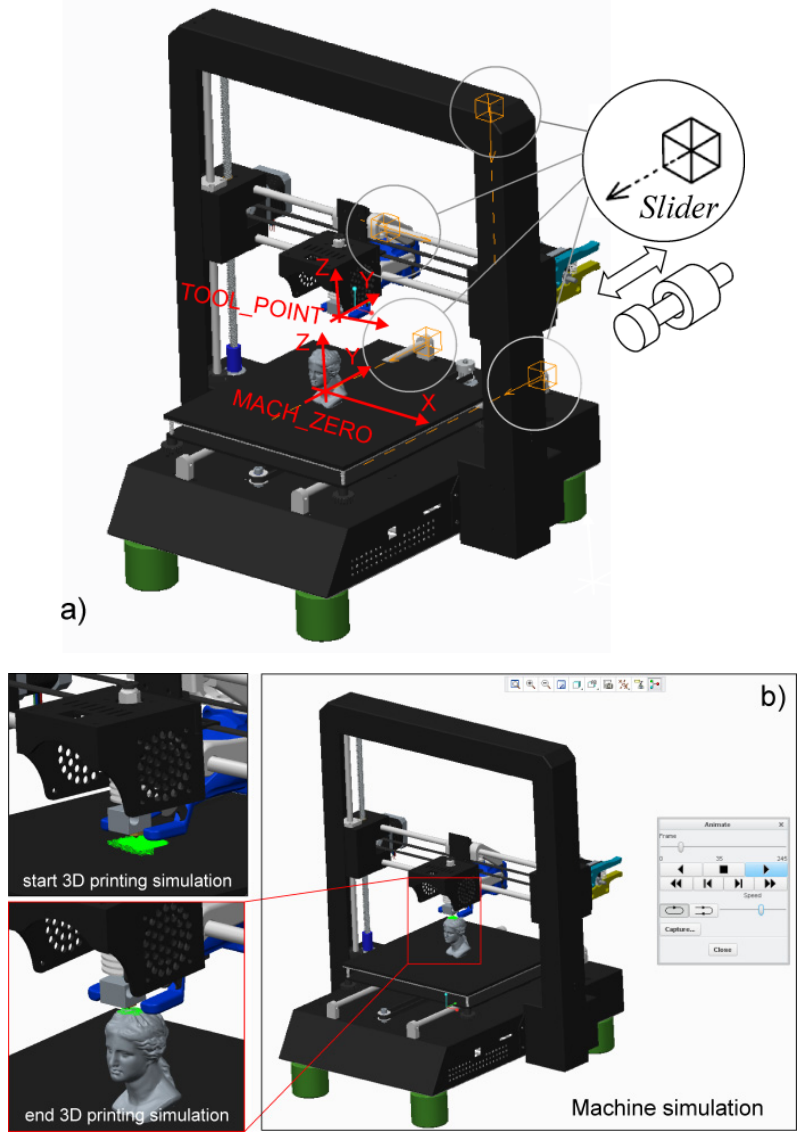

Figure 12. Machine simulation for FDM technology in CAD/CAM environment

To obtain the path for adding material, it is necessary to convert the path of the nozzle into G-code. Thus obtained path can be converted to the DXF file 
which can be loaded as a tool path into the CAM module. During the simulation, CAD model of the machine that is run based on the nozzle path for adding material can be include, Figure 12b.

Figure 13 shows the realization of the Venus model by the FDM technology on the Anycubic i3 Mega machine. By comparing Figures 12 and 13 it can be seen that the realistic process simulation in the $\mathrm{CAD} / \mathrm{CAM}$ environment is verified, which is one of the trends in digitization within Industry 4.0.
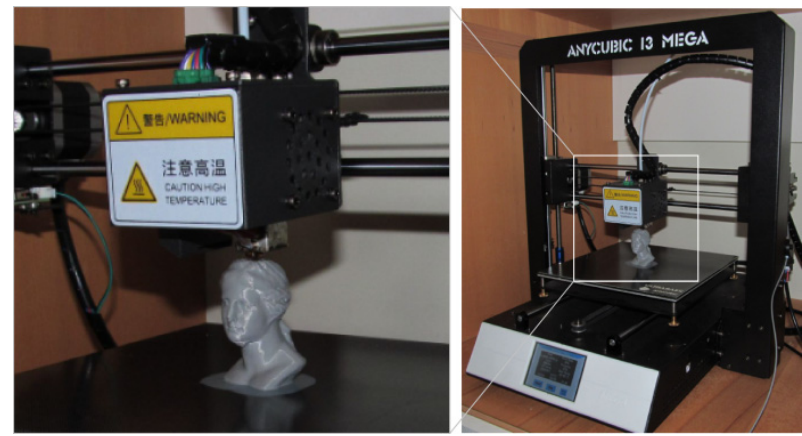

Figure 13. Fabricating prototype using FDM technology

\subsection{Rapid prototyping additive technology by adding and gluing layers}

Software package Autodesk 123D Make [14], allows creation of low-tech LOM (Laminated Object Manufacturing) style solid models. This software loads STL model based on which done slicing and preparing of layers for additive construction [7,14]. Realization of art sculpture shape Venus, using this software, is shown in Figure 14.

The new version of this program is known as Slicer for Autodesk Fusion 360 [15]. It allows making of complex parts, based on the 123D Make technology, and slicing and converting 3D models into 2D patterns that can be cut out of any flat material in order to make physical prototype of them. These 2D patterns are cut into thin layers and then the part can be fabricated by adding and gluing layers on top of each other.

First step in this procedure is loading the model (STL format) into the software and choosing the type of desired construction of the object. In the example presented, the construction type of adding parallel layers according to the model base (Stacked slices) was used.

After of loading the model in STL format, it is possible to choose the Slice direction, which is most appropriate for fabricating of physical model. Setting the basic parameters for fabrication of the model is done in the Manufacturing settings, where it is most important to choose the thickness of layer. The plan for cutting (2D pattern) of all the layers is done by choosing the Get Plans option. It is possible to choose two options for layers schedule: Simple or Nested, Figure 15. Nested layers schedule is a better option because it performs the optimal schedule of the layers on the cutting board, as shown in Figures 14e, and 15b. As an output from Get Plans options 2D plan of cutting in EPS, DXF or PDF formats can be obtained, Figure 14e. This plan can be used for cut using Laser cutter or CNC machine. The verification can be done using possibility of simulation of adding layer by layer, by option Assembly Steps, Figure 14f. The complete illustration of this kind of RP technologies was shown Figure 14.
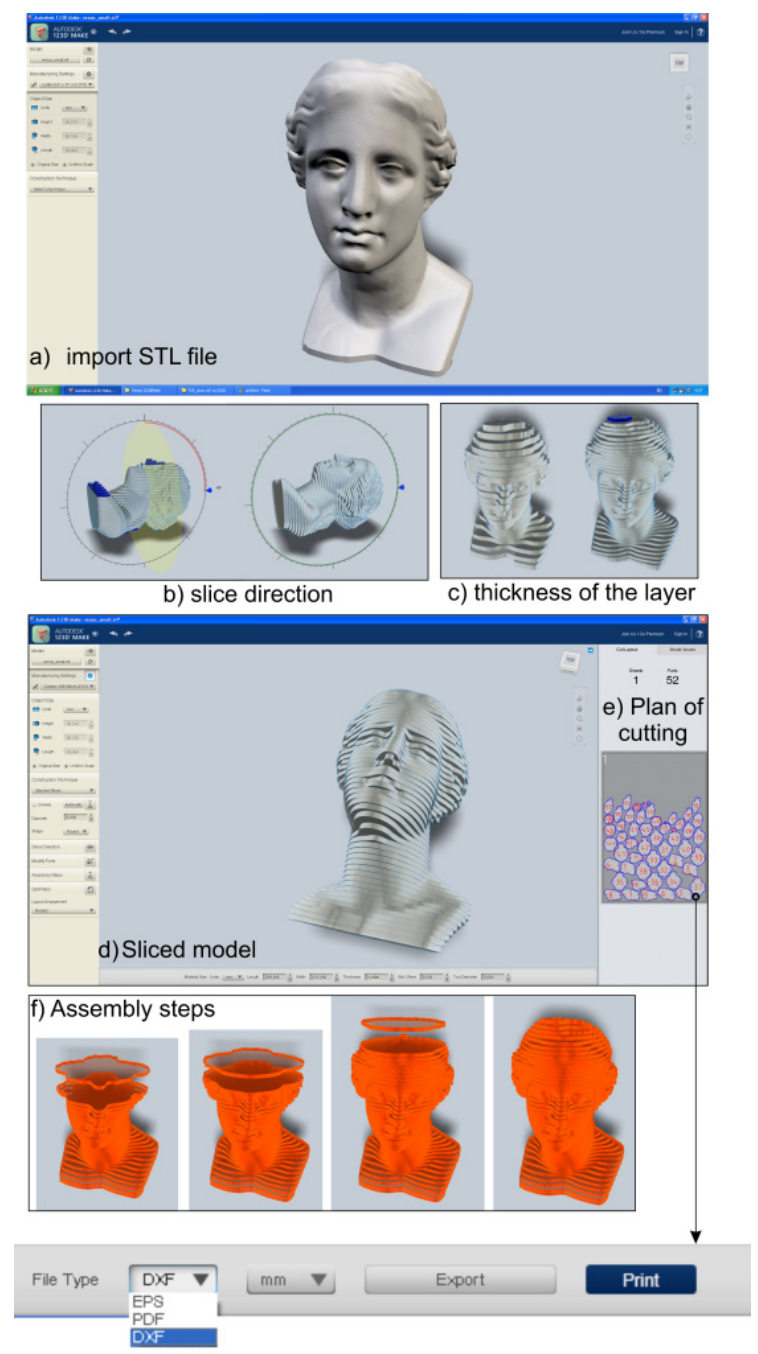

Figure 14. Rapid prototyping using software 123DMake

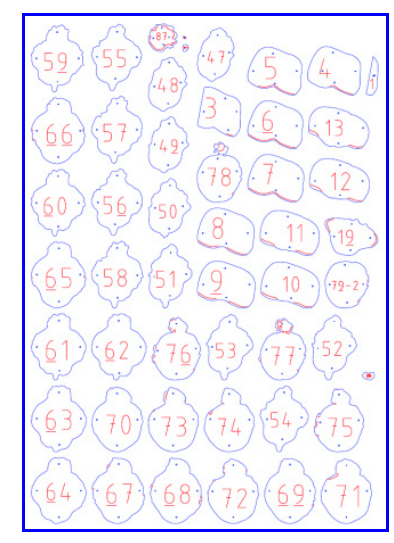

a) simple layer

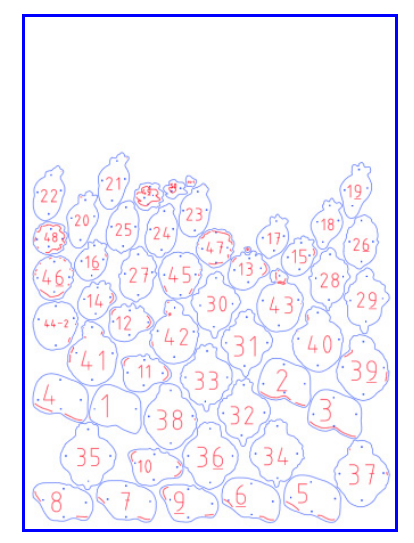

b) nesting layer

\section{Figure 15. Plan of cutting}

An example of the model obtained by cutting cartons with a thickness of $1 \mathrm{~mm}$ into layers and their gluing according to the instructions is shown in Figure 16. Each layer is positioned in relation to the previous layer by means of markers that are marked on each layer, and their order is defined by the numbers. Presented way of model obtaining is just an illustration of the additive technology by adding and gluing layers, 
since the thickness of the layer is large $(1 \mathrm{~mm})$ and therefore the obtained model is consists of very rough (stepped) surfaces. Using the thinner layers, a more accurate model can be obtained. This approach can be suitable for larger-scale models, where the thickness of the $1 \mathrm{~mm}$ layer would be satisfactory.
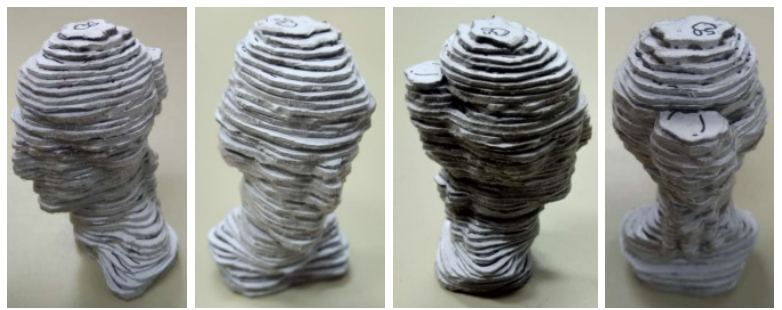

Figure 16. Model obtained by gluing layers of cardboard

\subsection{Rapid prototyping formative technology}

As an example of formative technology this paper shows silicone molding where the mold for making the Venus model was made using FDM. In the CAD/CAM environment, $\mathrm{CAD}$ models of mold halves are prepared based on the STL file of Venus model, Figures 17a, b. After that, both mold halves were made by the method of adding materials using the FDM technology, Figures $17 \mathrm{c}$, d. For casting the two-component silicone mass (Silicone Rubber KDSV-25) was used. It was first prepared for casting, Figure 17e, and then poured into the molds, Figure 17f, where hardening for 8 hours at the temperature of $23^{\circ} \mathrm{C}$. After opening the mold halves and finishing of model, silicone model was obtained, Figures 17g, h.
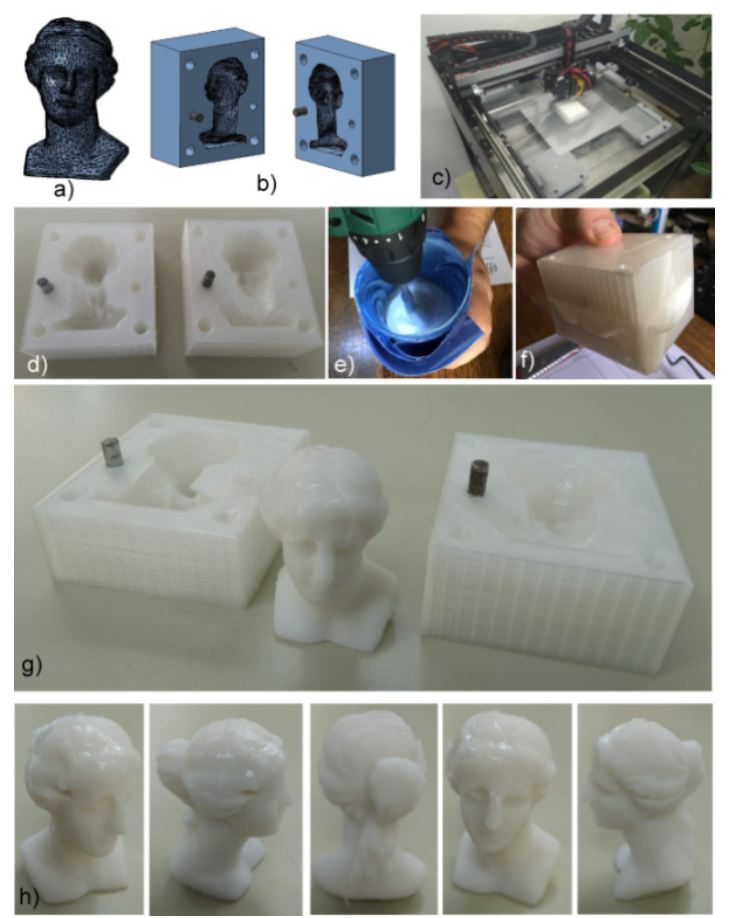

Figure 17. Rapid prototyping using additive FDM technology and formative technology

Production of such silicone models is suitable for obtaining the parts with negative geometry, which due to the elasticity of the silicone can be removed from the molds. This is just one of the possibilities of applying
RP formative technologies. The basic procedure involves the production of silicone mold halves that are formed on the basis of a prototype obtained by some RP technologies, mostly SLA (Stereolithography). The obtained silicone molds are used for casting a small series of plastic prototypes. This technology is known as Rapid Tooling or Soft tooling $[1,16]$.

\section{DISCUSSION}

Within this paper, the methodology for applying RP subtractive, additive and formative technology is presented. An overview of the manufacturing processes of model fabrication based on RP technologies are illustrated on the same selected example. The obtained prototypes by different RP technologies are shown in Figure 18.

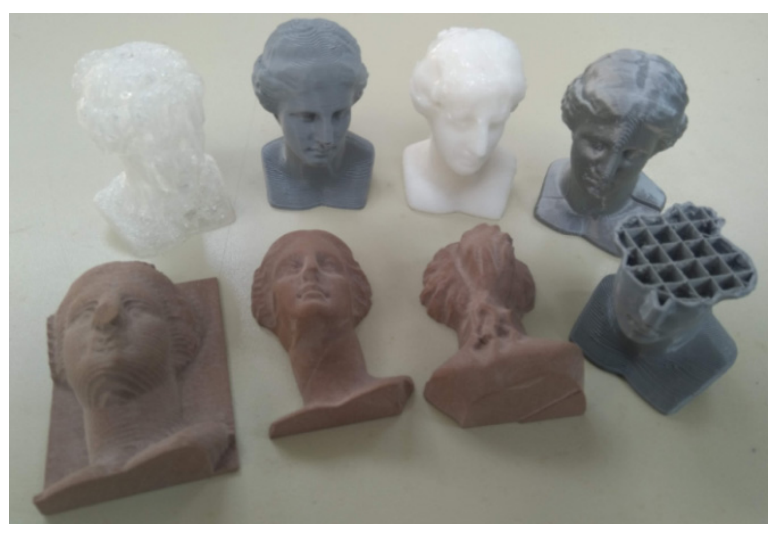

Figure 18. Different prototypes for the same model Venus

Milling, as subtractive RP technology, is done on a desktop 3-axis milling machine, where the model is divided into two halves. First, pre-machining was done, and then finishing of both halves of the model. A very satisfactory model was obtained, but with the basic lacks the impossibility of machining the surfaces with negative geometry. To overcome this, the processing is needed to be carried out on the $4+$ axis milling machines. This is not a problem with additive prototype fabrication or with the casting of prototype. As a method for additive RP technology, the FDM method with filament made of PLA (Polylactic acid) polymer of different colors and without supports was used. Models are obtained in two ways: as two halves of the model, and as a unique whole model. The first way is done in order to compare obtained two halves of the model with appropriate halves obtained by subtractive RP technology. The formative RP technology is presented by obtaining silicone prototype using mold halves that are get by FDM. The silicone prototype is successfully removed from the mold. Here it is only necessary to remove a very thin flash on the model after getting the model from the mold. All available RP technologies, methodologically considered in this paper, are verified by simulations of how part is created in appropriate software packages as well as by the successful fabrication of appropriate prototypes.

\section{CONCLUSION}

In order to contribute to acquiring experience in modeling, design, control, programming, verification 
and use of RP technologies, a methodology for rapid prototyping using subtractive, additive and formative technology is proposed.

Rapid prototyping technologies are successfully used by various industries where are important fabrication of concept models, functional models, patterns for investment and vacuum casting, medical models and models for engineering analysis.

This paper presented basic rapid prototyping technologies and generalized methodology for their application. These RP technologies are described through fabrication of examples based on the same Venus model in order to verify the proposed methodology.

The subsequent stages of research will involve the designing of benchmark model for additive manufacturing with goal of evaluating the accuracy and repeatability of rapid prototyping machines.

\section{ACKNOWLEDGMENT}

This work was funded by the Ministry of Education and Science of the Republic of Serbia under the contract TR35022.

\section{REFERENCES}

[1] Pham, D., Dimov, S.: Rapid Manufacturing: The Technologies and Applications of Rapid Prototyping and Rapid Tooling, Springer Verlag, London, 2001.

[2] Pham, D., Dimov, S.: Rapid prototyping and rapid tooling- the key enablers for rapid manufacturing, in: Proceedings of the Institution of Mechanical Engineers, Part C, 217, pp. 1-23, 2003.

[3] Gibson, I., Rosen, D. and Stucker, B.: Additive Manufacturing Technologies, 3D Printing, Rapid Prototyping, and Direct Digital Manufacturing, 2nd Edition, Springer New York Heidelberg Dordrecht London, 2010.

[4] Rapid Prototyping Brandenburg University of Technology Cottbus February 2010, from https:// docplayer.net/23305643-Rapid-prototyping-brandenburg-university-of-technology-cottbus-february2010-seppo-aarnio.html, accessed on 2019-5-07.

[5] Sljivic, M., Pavlovic, A., Ilic, J., Stanojevic, M. and Todorovic, S.: Comparing the Accuracy of Professional and Consumer Grade 3D Printers in Complex Models Production, FME Transactions, Vol. 45, No. 3, pp. 348-353, 2017.

[6] Popa, D.L., Buciu, G., Calin, D.C., Popkonstantinovic, B., Poenaru, F.: CAD, CAE and Rapid Prototyping Methods Applied in Long Bones Orthopaedics, FME Transactions, Vol. 47, No. 2, pp. 279-286, 2019.

[7] Zivanovic, S.: Rapid prototyping and manufacturing for model of human head. in: Proceedings of the 8th International Scientific Conference IRMES 2017, Trebinje, Bosnia and Herzegovina, pp. 271276, 2017.
[8] Chua, C.K., Leong, K.F., Lim, C.S.: Rapid Prototyping: Principles and Applications, 2nd Edition, World Scientific Publishing Co. Pte. Ltd., 2003.

[9] Singh, V. K., Chauhan, N.S.: An overview of rapid prototyping technology, International Journal of Application of Engineering and Technology, Vol. 2, No.3, pp. 224-227, 2015.

[10]Fusion 360, Free 3D CAD, CAM, and CAE software for students and educators, from https:// www.autodesk.com/products/fusion-360/studentsteachers-educators, accessed on 2019-6-20.

[11] Integration Definition for Information Modeling (IDEF1X), Federal Information Processing Standards Publication 184, National Institute of Standards and Technology, 1993.

[12] PTC, Creo Parametric, from http://www.ptc.com/ $\mathrm{cad} / \mathrm{creo} /$ parametric , accessed on 2019-6-25.

[13] Stratasys, from, http://www.stratasys.com, accessed on 2019-6-25.

[14] Autodesk 123D Make, from http://autodesk-123dmake.en.lo4d.com/, accessed on 2019-6-25.

[15] Slicer for Autodesk Fusion 360, from https:/ /www.autodesk.com/products/fusion-360/blog/ quick-tip-slicer-fusion-360/, accessed on 2018-1211.

[16] Chua, C.K., Leong, K.F., Liu, Z.H.: Rapid Tooling in Manufacturing, Handbook of Manufacturing Engineering and Technology, Springer-Verlag London 2013.

\section{ПРЕГЛЕД ТЕХНОЛОГИЈА БРЗЕ ИЗРАДЕ ПРОТОТИПОВА ПОМОТУ СУБТРАК- ТИВНИХ, АДИТИВНИХ И ФОРМАТИВНИХ ПРОЦЕСА}

\section{С. Живановић, М. Поповић, Н. Воркапић, М. Пјевић, Н. Славковић}

Овај рад описује методологију за примену брзе израде прототипова применом субтрактивних, адитивних и формативних технологија на основу STL фајлова. Технологије брзе израде прототипова укључују дигитални ланац информација CAD/CAM /CNC, до нивоа који омогућава успешну реализацију физичких модела користећи нову технологију, додавањем, одузимањем и обликовањем материјала. У раду су разматране уобичајене технологије брзе израде прототипова, за које је предложена генерализована методологија за њихову примену. Показане су и могућности за верификацију програма пре саме израде модела. Методологија је верификована на конкретним примерима израде изабраних делова користећи технологије одузимања, додавања материјала слој по слој, и израде калупа (додавањем материјала) за ливење модела од силикона. 